What I must have meant to say is, that the sodium sulphide appears like a precipitate, i.e. as a powder, in the partly dissolved mass. The reason of its appearing to be black on aluminium, and not, as it ought orthodoxically to be, brown, I cannot tell, as the metal is not attacked. Perhaps my reviewer can? I only say that it is so.

May I take this opportunity of soliciting you to afford, if possible, a little more space in your valuable journal, to the admittedly neglected subject (in England) of blowpipe analysis? It is, I can assure any of our chemists who have not much employed it, a most fascinating study, which will amply repay any leisure time expencied upon it.

W. A. Russ

\section{Meteor in the Daytime}

DEC. 22 , about 2 P.M., as our servants were sitting at dinner by the kitchen window, two of them were startled by the sudden appearance of a brilliant meteor descending in the $\mathrm{E}$. with a Hitle inclination to the $\mathrm{N}$. It was not as large as the moon, but much larger than Mars or Saturn, white, and like lightning, with a very quick course, leaving a train as broad as itself, and preserving its full size till it was lost behind the top of an oak tree at a little distance, whose branches, though leafless, seem to have concealed it from view. The next day $\hat{I}$ found by means of a compass and a joined ruler, that its azimuth was E. by N., its inclination towards $N$. about $10^{\circ}$, the upper window frame, where it probably came into sight, $48^{\circ}$, and the top of the tree $2 \mathrm{I}^{\circ}$ above the horizon. I have not, as yet, heard of any other observation of this remarkable meteor. The position of Hardwick Vicarage, where it was seen, according to the Ordnance Map, is Long. W. $3^{\circ} 4^{\prime} 23^{\prime \prime}$, Lat. N. $52^{\circ} 5^{\prime} 20^{\prime \prime}$

T. W. WEBB

\section{Protective Resemblance in the "Sloths}

As "mimicry" and "protective resemblance" have chiefly been noticed among insects and the lowest of vertebrated animals, the following observation regarding the three-toed sloth, made at the beginning of this century, and therefore much in advance of the period at which attention had been directed to this subject, is, in these days, not without interest. It is taken from a work not frequently met with, namely, Baron Albert von Sack's "Narrative of a Voyage to Surinam" (London, I8Io). In chap, xvi. at p. 170 , he says :- "The colour and even the shape of the hair are much in appearance like withered moss, and serve to hide the animal in the trees, but particulariy when it gets that orange-coloured spot between the shoulders, and lies close to the tiee; it looks then exactly like a piece of branch where the rest has been broken off, by which the hunters are often deceived." The colour of the hair of the body is thus distributed in Arctopitretus castaneiceps, A. grisetus, and $A$, flaccidus ("Notes on the "Species of Bradypodidre in the British Museum," by the late Dr. J. E. Gray. Proc. Zool. Soc., 1871, p. 428, Plates xxxy.xxxvii.).

Brants, in his "Dissertatio Zoologica Inauguralis de Tardi. gradis" (Lugdun. Batav., 1828), p. 28, says of the sloths :- "At provida natura, cum animanti negaverit arma et tela, velleri cum colorem tribuit, quo subducatur oculis ferarum et adversariorum Fere eadem ratione, ac Pallas retulit de Pteromye volante." The passage to which reference is made is in the "Nova speciesquadrupedum e glirium ordine," p. 357 :- "Dum vero in Betuletis prexsertim vitam agunt, sapienter a natura perspectum est, ut omni tempore anni exalbido canescentem colorem velleris servent, quo cortici betularum ita frunt similes, ut scandentes vix, imo sub diluculum, quo tempore præsertim excurrunt, plane non conspici eminus possint, coque ab avibus rapacibus nocturnis securiores sunt," Reference is also made to Prince Maximilian of Nieuwied's "Beiträge zux Naturgeschichte von Brasilien," tome ii. S. 480 .

J. C. GaLton

Dec. 29,1875

\section{Coffee in Dominica}

iv Nature (vol. xiii. p. 38 , and under the head of "Coffee in Dominica"), it is stated that the "falling off in the cultivation of the coffee plant, in a scil and climate which experience showed was eminently suited to it in every respect, was due to the extensive destruction of the plants by what was there known as the coffee blight." The foregoing statement requires this qualification, that after the appearance of the coffee blight, and when the coffee crop was gradually decreasing in quantity, the old coffee planters made no attempts to check the ravages of the destroying insect, but, in many instances, cut down the valuable trees, planted the sugar-cane, and converted their coffee-works into sugar-works. I could mention the names of several estates where what I have described was done. I think it right also to add that in some portions of Dominica, where the coffee-trees were simply abandoned, they now stand, , and, considering their age and the neglect to which they have been exposed, they bear fairly well. During the last two years, and since the disastrous fall in the price of cane sugar, $I$ have been endeavouring to reintroduce here the coffee cultivation, and, on the Tabery estate, 12,000 young trees of my own planting are doing well. You will confer a great and lasting benefit upon this beautiful but neglected and almost unknown island by calling attention to its capabilities as a coffee-producing country.

South Chiltern, Dominica, Dec. $11, x 875$

EDMUND WATT

\section{The Law of Storms}

I HAVE to thank you for publishing, in NATURE of Dec. 2, I875, my letter in reply to $M$. Faye's theory of cyclones, and I have now to submit some remarks on his theory of waterspouts.

I understand him to maintain that the dark part of the waterspout, which we see, contains a core of transparent air, which is descending at the centre of a vortex, and that the dark visible external part is a cloud formed by an ascending counter-current.

All this is unproved, and I think baseless. No dynamical reason can be assigned why there shonld be a downward current at the centre of the vortex. If the waterspout is formed in a vortex, which I think probable, though I am not certain of it, the vortical motion will produce not a downward but an upward current at its centre, in consequence of the diminution of barometric pressure, due to the air being thrown to the circumference by the centrifugal force. We see such upward currents formed in the little dust-whirlwinds that form themselves over streets and roads in windy weather.

Further, if M. Faye's theory were true, and if the waterspout were transparent at the centre, it could not be so well defined and solid as it usually is, nor could it be formed so rapidly.

The true theory of waterspouts is expounded in Espy's "Philo. sophy of Storms," a work which, notwithstanding its great error of cenying the rotation of cyclones, made an era in meteorology, and, so far as I arn aware, is not yet superseded.

When vapour is condensed into water, forming clond, the latent heat of the vapour is liberated and expands the air. A simple calculation shows that, after deducting the destroyed volume of the condensed vapour, the increased volume of the air due to this expansion is berween four and five times as great as the volume of the vapour before condensation. If, then, the air is nearly saturated with moisture, and the temperature in a state of convective equilibrium for dry air (that is to say, when the difference between the temperatures of any two strata is that due to the difference of their pressures), and condensation begins in any column of air, the effect of liberating this heat will be to make the air of that column warmer and lighter than the air at corresponding heights in the surrounding columns. What follows is from Espy's work, page 44 :-

"It begins, by its diminished specific gravity, to rise, and then, if all circumstances are favourable, the cloud will increase as it ascends, and finally become of so great perpendicular depth, that by its less specific gravity the air below it, in consequence of diminished pressure, will so expand and cool by expansion, as to condense the vapour in it; and this process may go on so rapidly that the visible cone may appear to descend to the surface of the sea or earth from the place where it first appears, in about one or two seconds. The terms here em. ployed must not be understood to mean that the cloud actually descends; it appears to the spectator to descend, but this is an optical deception, arising from new portions of invisible vapour cunstantly becoming condensed, while all the time the individual paricles are in rapid motion upwards."

Tothis I will add as very probable, if not quite certain, that the rarefaction thus caused at the waterspout will produce an inflow of air from all sides, and this will produce a vortex at the centre; this again, by its centrifugal force, will increase the rarefaction, and thus will intensify the effect. But the com. mencement of the waterspout is in the way described by Espy in the above extract.

JOSEPH JOHN MURPHY

Old Forge, Dunmurry, Co. Antrim, Dec. 12, 1875 